\title{
MEMAKNAI KEMBALI SPIRITUALITAS ISLAM DALAM PERADABAN KONTEMPORER
}

\author{
Oleh: Baedhowi
}

\section{Abstract}

This article tries to describe the reinterpretation of the Islamic spirituality in contemporary era. The writer explores the short history in sufism as a source of Islamic spirituality. He also wants to explore how to interprete the sufism as a product of history. From its history, we can know the developement of sufisme period to period. In other hand, we can also reinterprete the meaning of Islamic spirituality in the contemporary civilization or modernism point of view. For example, we can know how to reinterprete the concept of "wahdat al-wujûd" and "wahdat al-adyân" as a main part of spirituality in Islam. This reinterpretation is expected to contribute the moral ethic or spirituality in contemporary era.

\section{خماهدة}

حاول الباحث في هذه المقالة تقديم صورة لإعادة تفسبسي دوحانية الإسلام في عصر الحليث

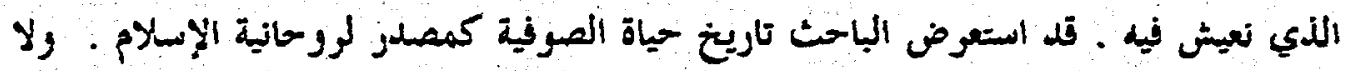

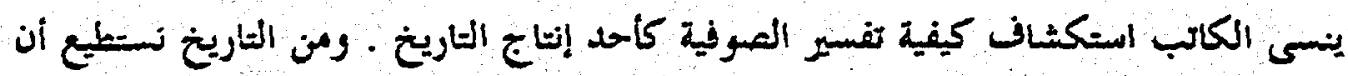
نعوف تطور الصوفية من خلال التاريخ والعصور . وبجانب ذلك نستطيع أن نقوم بإعادة تفسير

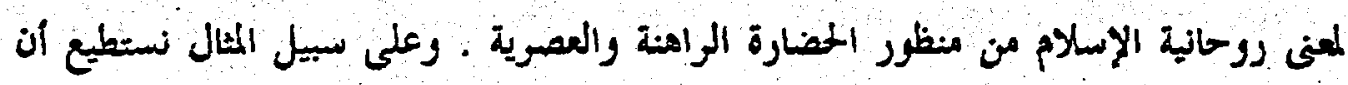

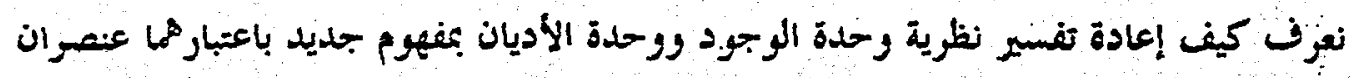
من عناصو روحانية الإسلام ، ومعنى الملديل لورحانية الإسلام تساهم ويقوم بالدور المام لمعالجدة

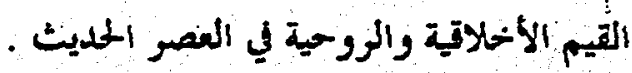

Kata Kunci: Spiritualitas Islam, Etika Peradaban, Kontemporer.

"Penulis adalah Dosen di STAINU Temanggung. Jawa Tengah 


\section{A. Pendahuluan}

10 alam kesempatan general review matakuliah filsafat agama yang diampu oleh Amin Abdullah, penulis "dibebani" untuk membuat refleksi atas berbagai persoalan filosofis dalam agama-agama. Makalah-makalah yang disajikan dalam kuliah tersebut memang menjelajahi dan menyoroti berbagai persoalan yang berkaitan dengan keagamaan atau epistemologi dan ideologi yang cenderung menjadi "agama baru"

Tugas tersebut secara reflekstif cukup menggelisahkan penulis. Bukan hanya sekedar" temanya yang cukup menantang dan "provokatif", yakni : "Does God have a Future ?" Tetapi lebih dari itu, karena realitas empiris kontemporer menunjukkan bahwa keberadaan spiritualitas agama-agama banyak mengalami pemiskinan secara praksis. Maraknya tindak kekerasan, seperti terorisme, ledakan bom di berbagai tempat di tanah air hingga agresi militer tentara AS cs ke Irak yang semua itu meski tidak mengatasnamakan "perang" agama, namun para pelaku tindakan tidak beradab tersebut mestilah orang yang beragama. Tindakan-tindakan destruktif tersebut kiranya juga adalah bisa menjadi warning atas semakin menguatnya peradaban global sekaligus mengisayaratkan akan menipisnya nilai-nilai spiritualitas dan etika global dalam peradaban tersebut.

Tema-tema dalam kuliah filsafat agama memang diarahkan untuk menjelajahi persoalan model metafisika klasik, gejala"ateisme"akibat sekularisme dan perkembangan peradaban pengetahuan (seperti model positivisme logisnya kelompok Wina (Weiner Kreises) yang dimotori Rudolp .Carnap cs), kecendrungan menguatnya kembali fundamentalisme, modelmodel spiritualitas dari tokoh-tokoh agama (Muslim, Yahudi, Kristen) dan bentuk spritualitas agama-agama atau "sketsa" Tuhan di masa depan:

Karenanya dalam tulisan ini penulis mencoba mengekplorasi kembali bagian dari kegelisahan spiritualitas tersebut, yaitu konsep "wahdat al-wujûd" dan "wahdat al-adyân" dan mengelaborasinya sebagai sampel model spiritualitas Islam.

\section{B. Setting Historis Sufisme}

Pada masa awal Islam, tasawuf atau sufisme memang belum dikenal apalagi sebagai sebuah ajaran atau ilmu yang spesifik. Pada masa Nabi Muhammad dan para sahabat istilah yang lebih mudah untuk dipahami adalah jiwa dari ihsân ${ }^{1}$, dimana seorang mukmin selain merasa dekat dengan Tuhan juga selalu dipantau oleh Nya. Penghayatan makna ihsân tersebut bisa menjadi

'Ihsan dalam hadits dilukiskan bahwa kamu "menyembah Allah seolah-olah kamu melihat-Nya, jika kamu tidak melihatnya maka yakinlah bahwa Allah melihatmu" (al-ihsain: an ta'buda allâha kaännaka tarâhu, fa in lam takun tarâhu fa innahu yarâka) 
dasar-dasar kuat bagi sufisme. Jiwa ihsân tersebut terlihat sekali dalam keteladanan yang dicontohkan melalui kehidupan Nabi saw. Keteladanan semacam ini sebenarnya merupakan cerita hidup (living story) yang amat kaya makna. Baik ketika ia masih belum diangkat menjadi Nabi dan rasul dan sering berkontemplasi (tahannuts) di gua Hira'. Pengalaman religius ini berpuncak pada turunnya wahyu pertama, yakni pada saat Ia hanyut dalam lautan renungan yang dalam. ${ }^{2}$ Pengalaman spiritual ini kian intens hingga terbuka tabir kegaiban oleh kemurnian jiwanya, terutama pada puncak pengalaman rohani Nabi ketika melakukan perjalanan isra' dan Mi'raj.

Pendek kata sunnah dan sirah Nabi telah diteladani langsung oleh para sahabatnya dalam berbagai profesi mereka masing-masing. Mereka meniru bagaimana kejujuran ketika Nabi berdagang, keikhlasan memegang-amanah, kasih sayang dan kebijakan beliau ketika memimpin, hidupnya yang zuhud dan sering menjauhkan diri dari hiruk pikuk dunia sekitarnya dalam mencari Kebenaran dan Hakekat sehingga lupa diri, makan dan segala yang berkaitan dengan kehidupan. Kesungguhan konsentrasi dan kontemplasi Nabi akhirnya menemukan jalan keluar dari problem masyarakat dan mencapai tingkat spiritualitas yang tinggi. Ia bahkan sampai mencapai musyâhadah albathinîyyah yang pada gilirannya setara dengan spiritualitas malaikat yang menerima wahyu. ${ }^{3}$

Figur, keteladanan (uswah) Nabi dan lebih-lebih kehidupan kerohanian beliau telah menjadi acuan spiritualitas bagi ummatnya. Pada masa sahabat Khulafa" al-Rasyidun jelas juga merupakan "mutasswifûn" dengan tipe dan karakter kepemimpinan mereka masing-masing. Mereka selain dikenal dalam prilaku asketis dan sikap zuhud juga muncul pula sahabat-sahabat Nabi yang dikenal dengan $A$ hlu al-Suffah. Kelompok sahabat ini selain tertarik dengan hal-hal yang bersifat batiniah, seperti melakukan dzikir dan meditasi mereka juga lebih memilih hidupa fakir. Ahlu al-Suffah yang terdiri dari sahabat Muhajirin dan Anshar ini meski sangat miskin mereka tidak mau memintaminta (QS 2: 273). Mereka juga dipuji Allah (QS, 16: 18) karena selalu bersabar dalam menjalani kehidupan, selalu berdzikir setiap saat. Bahkan Nabi juga diperingatkan agar jangan memalingkan mukanya dari mereka karena hanya sekedar menginginkan kehidupan duniawi. Dalam kepapaannya mereka tidak pernah susah kecuali dalam soal-soal yang dapat memperkuat kehidupan akhirat mereka. ${ }^{5}$ Sikap zuhud para sahabat, selain dipraktekkan oleh al-

${ }^{2}$ Fazlur Rahman, 1979, Islam, Chicago: Chicago Univ. Press., hal. 11.

${ }^{3}$ Ibnu Khaldun, tt, al-Muqadimah, Beirut: Dâr al-Fikr, hal. 78.

Nurcholish Madjid, 1992, Islam Doktrin dan Peradaban, Jakarta: Paramadina, hal.

25.

5Thabataba'i, tt., al-Mizân fi Tafsir Âyât al-Quir ân, Jama'ah al-Darrisin, Qum alMuqaddasah, hal. 303. 
khulafa' al-rasyidun dan Ahlu al-Suffah, secara khusus juga dipraktekkan tokoh-tokoh seperti Abu Hurairah, Abu Zar al-Ghafai dan sebagainya. ${ }^{6}$ Sikap semacam ini akhirnya dalam teori sufisme menjadi tahapan (station) tersendiri bagi seorang salik untuk memasuki dunia spritualitas Islam.

Dari gambaran sufisme di masa sahabat dan masa permulaan Islam nama tasawuf (sufisme) ${ }^{7}$ bisa dikatakan belum ada, tetapi hampir setiap sahabat bisa dikatakan sebagai para sufi. Keadaan ini tampaknya berbanding terbalik dengan situasi sekarang bahwa nama tasawuf ada namun hanya ada sedikit kaum sufi. Atau meminjam seorang sufi Maghribi yang namanya besar di Perancis bahwa: "pada mulanya sufisme merupakan realitas tanpa nama, sedangkan masa sekarang sufisme merupakan nama tanpa realitas".

Fase puncak keagungan kehidupan spiritual ruhaniah Nabi di atas kemudian secara historis (sejak abad ke-7) dan spesifik hendak diacu pengikutnya dan menjelma dalam praktek tokoh-tokoh sufi yang berporos sentral di Baghdad dengan tokoh-tokoh seperti Muahasabi (w.243H/857M), alBustami, (w.260H/874M), Tirmidzi (w.285H/898M), Gunaid (298H/910M), al-Hallaj (w.309H/922M). Kemudian diikuti oleh tokoh tokoh lain (tasawuf ilmi) yang secara tehnis manual telah menghasilkan dan memberikan kontribusi kata-kata kunci, seperti Abu Nasr as-Saraj (w. 378H/988M), dengan karyanya Kitâb al-Luma' fi 'ilmi al-Tashawwuf, Kalabadi (w. 388H/998M), dengan Kitab al-Ta'âruf, Abu Thalib al-Maki (w.386H/996M) dengan Qutb alQulûb, al-Ghazali dengan Ihyâ'nya dan seterusnya. ${ }^{9}$ Atau munculnya tokoh di luar Baghdad misalnya seperti Ibnu Arabi, Sadruddin al-Qumyani, Jalaluddin ar-Rumi dan Najmuddin Qubra. ${ }^{10}$

Namun dari pengalaman historis, penjelajahan kata-kata teknis dan metodologi dalam sufisme menurut Arkoun tampaknya secara esensial ada

dst.

${ }^{6}$ Amin syukur, 2000, Zuhud di Abad Modern., Yogyakarta: Pustaka Pelajar, Hal. 32

"Arti tasawuf sendiri bersifat multi definitif, tetapi dalam dunia tasawuf ada gejala konstan dan serupa yakni rasa kerinduan universal manusia akan "kemanungalan dirinya dengan Tuhan. Sedangkan secara etimologis artinya $a^{*}$ l: a. Ahlus Suffah, b. Shaf (barisan dalam shalat), c. Suufi (orang suci), d. Sophos (hikmah), e. Shuf (kain wol). Arti terakhir kini konon yang terpopuler karena kebiasaan kaum sufi selalu memakai kain wol kasar sebagai lambang kemiskinan dan kesahajaannya. Lihat Harun Nasution, 1973, Filsafat dan Mistisme dalam Islam, Jakarta: Bulan Bintang, hal. 73.

${ }^{8}$ Syeikh Kholed Bentounes kolaborasi dengan Bruno \& Roman Solt, 1996, Le Sufisme couer de l'Islam les Valeurs universelles de la mystique Islamique, Paris: La Table Ronde. Hal. 53.

42.

${ }^{9}$ Mohammed Arkoun, 1984, Essais sur la pensee Islamique, Paris Maisonneuve, hal.

${ }^{10}$ Sayyid Hussein Nasr, 1985, Living Sufism. Alih Bahasa Abdul Hadi WM. Jakarta: Pustaka Firdaus, hal. 111. 
kesamaan, yakni ia bersandar pada psikologi evolutif (tadmîn; introspeksi/langkah ke dalam). Di sana ada tiga tingkatan yang harus didalami dalam tabiat manusia (nasûtiyya). Pertama dan yang paling lahiriah adalah memahami seluk beluk jiwa atau nafsu (nafs). Ia merupakan sarana perjuangan agung (jihâd al-akbar) untuk kemudian melampaui berbagai tahapan (stations/maqâmat), yakni: tawbah, zuhd, faqr, shabr, tawakkal dan ridha hingga mencapai tingkat kedua, kalbu. Hati adalah sebagai pembanding (muqâbalah) dan tempat yang paling pas dan ampuh terhadab berbagai perlawanan yang saling berkaitan (ahwal), seperti raja' -khowf, bast - qabd, uns - hayba dan sebagainya. Seorang sâlik setelah mengetahui al-ahwâl sebagai sebuah anugrah yang diberikan Tuhan atas kesucian hati dan kesiapan mentalitasnya (terutama dengan persiapan dan latihan dalam maqâmat), maka ia akan mengalami kenikmatan yang memuncak (extace) hingga ke arah penghayatan pertemuan dengan Tuhan (ittishâl) dan kesatuan dengan-Nya (ittihâd). Cara-cara peningkatan spiritualitas kaum sufi tersebut juga disistimatisasikan oleh Arkoun dalam sebuah skema sebagai berikut ${ }^{11}$ :

Dlahir nafs tawbah - warâ' - zuhûd - faqr - shabr - tawakkul - ridhâ - Fanâ' maqâmat (berkaitan dengan masa)
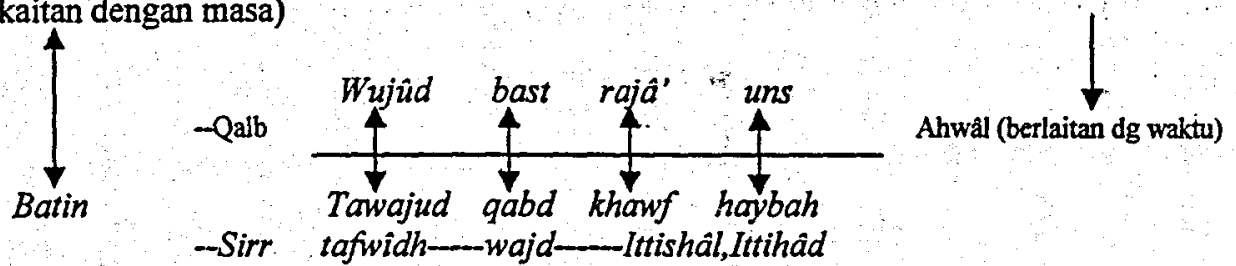

Dari paham mistis kaum sufi di atas tampaknya memang ada kecendrungan ke paham patheisme. Ini karena upaya mereka telah menghasilkan penghayatan dimana antara yang dilihat sama dan sederajat dengan yang melihat. Mereka yakin bahwa yang dilihat melalui ketajaman mata batin (bashirah) itu Tuhan. Maka mereka berkesimpulan bahwa Tuhan dan diri sufi adalah satu. Kewajaran dalam kecendrungan pantheisme itu karena dalam pengalaman fana' yang dicapai di tengah keasyikan dzikr allâh. Ini berarti hilangnya kesadaran akan existensi dari pribadinya (hilangnya quasi total kesadaran diri) dan telah lebur dalam Tuhan (ittihâd) atau union mystic. ${ }^{12}$ Kecenderungan semacam ini terlihat sekali dalam tokoh-tokoh sufi seperti alBustami, Mansur al-Hallaj dan Ibnu Arabi. Faham ittihâd ini dalam dua tokoh tersebut terakhir tampak jelas. Cuma dalam diri al-Hallaj berubah menjadi faham "hulûl" atau inkarnasi menempatnya ruh Tuhan dalam diri manusia.

\footnotetext{
"Arkoun, Essais, hal. 43.

${ }^{12}$ Harun Nasution, 1978, Filsafat Islam dan Mistisisme dalam Islam, Jakarta: Bulan Bintang. Hal. 81.
} 
Sedangkan dalam faham Ibnu Arabi berubah menjadi paham pantheisme, yakni faham kesatuan dan kesamaan antara Tuhan, alam dan manusia atau paham serba Tuhan. ${ }^{13}$

\section{Nalar Irfânî dan Humanisme Religius sebagai Produk Historis}

Dua istilah, nalar 'irfânî dan humanisme religius adalah istilah yang sengaja penulis gunakan untuk dunia mistikisme (sufisme). Kedua istilah tersebut juga telah menjadi trade mark dua pemikir Islam kontemporer, yakni Muhammad 'Abid al-Jabiri ${ }^{14}$ dan Mohammed Arkoun. ${ }^{15}$ Dari kedua tokoh tersebut tampak bahwa metodologi dan pendekatan dalam pengkajiannya menempatkan berbagai kemajuan ilmu-ilmu sosial mutakhir untuk mengurai dan menjelaskan suatu epistemologi dalam sebuah produk pemikiran. Penulis juga terkesan dengan cara yang digunakan oleh kedua tokoh ini, terutama dalam mengkritisi sebuah produk pemikiran. Tasawuf sebagai sebuah wujud spritualitas Islam tampaknya juga tumbuh berkembang mengikuti tantangan zamannya. Ia bukan produk jadi yang steril dari ruang dan waktu sehingga menjadi produk yang suci dan tak boleh tersentuh kritik. Secara metodologi Spiritualitas Islam yang termanisfestasi dalam sufisme sebagai produk historis sebuah pemikiran menurut Arkoun bisa ditelaah kembali dengan cara-cara Ishlâh. ${ }^{16}$ Cara membaca secara kritis semacam ini, misalnya telah penulis gunakan untuk "Menelaah Pemikiran Tasawwuf al-Ghazali" '7 Zuhud dalam

${ }^{13}$ Faham pantheisme Ibnu Arabi ini konon telah mempengaruhi tokoh mistis Katholik Jerman, Meister Eckhart (abad ke-13) di mana ia justru mengembangkan pahamnya menjadi faham panentheisme (faham bersemayamnya ruh Tuhan dalam setiap benda). Lihat Mathiew Fox, 1980, Breakthrough: Meister Eckhart's Creation Spirituaity in New Transition, New York: Doubleday, hal. 23 dst.

${ }^{14}$ Lihat M. Abed al-Jabiri, Cet. ke-4, 1992, Bumyah al-Aql al-Arabi, Beirut Markaz Dirasah al-Waihdah al-Arabiah. Istilah Irfani dalam konsep Jabiri tampak lebih difokuskan pada bangman epistemologi nalar Arab (sufisme) yang telah menyejarah.

${ }^{15}$ Mohammed Arkoun, 1982, Humanisme Arabe au IV/X siecle, Paris. Libraire Philosophique. Sedangakn Istilah humanisme yang dipakai Arkoun tampaknya untuk membidik wilayah yang lebih luas (sampai wilayah epistemologi non Arab), yakni wilayah keagamaansecara umum.

${ }^{16}$ Lihat Mohammed Arkoun, 2003, "Rethinking Islam" dalam Peta Studi Islam, Yogyakarta: Pustaka Baru, hal, 317-18. Metode pendamaian (ishlâh) model Arkoun ini sebenamya merupakan metode historis (historisme) dan dekonstruksi Arkoun dalam menjelasakan sebuah pemikiran. Cara ini dipinjam dari Jacque Derrida dan lembaga sejarah Perancis, les annales. Metode ini dilakukan dengan membongkar sebuah produk pemikiran dan diurai secara historis guna menemukan bentuk epistemologi dan muatan ideologis dari pencetus konsepsi pemikiran. Bandingkan dengan Baedhowi, "Tasawuf Sebagai Jalan Menuju Kebenaran", hal. 302, cat. 37.

${ }^{17}$ Lihat Baedhowi, 2003, "Tasawwuf Sebagai Jalan Menuju Kebenaran: Kajian Pemikiran al-Ghazali", dalam Millah, Vol. II, No 2, Magister Studi Islam UII, Yogyakarta, hal.292-306. 
praktek para tokoh bisa jadi memang murni prilaku asketis dan keyakinan spiritualitasnya. Namun sikap zuhud bisa juga berarti sebuah wujud protes sosial atas berbagai kedzaliman dan ketamakan penguasa.

Sebagai sebuah produk pemikiran, sisi minus spiritualitas Islam (sufisme) hemat penulis secara parsial sering ditampilkan dalam spiritualitas kaum fundamentalis dan tradisionalis dalam eksklusivitas sikap dan prilaku yang rigid, dogmatis, dan intoleran atas klaim kebenarannya sendiri. Prilaku semacam itu bisa jadi berwujud dalam ordo-ordo sufisme yang tidak reformatif yang menurut Fazlur Rahman sering mengkrucut menjadi "religion within religion" ${ }^{18}$ Sisi minus spiritualitas Islam dalam sufisme secara individual juga telah banyak melahirkan orang-orang shalih, namun secara kemasyarakatan kadang belum melahirkan kesalihan sosial yang signifikan. Sehingga dampaknya juga sering belum dirasakan secara global dan massif. Sisi-sisi negatif dan parsial dari spiritualitas Islam dalam humanisme religius semacam ini sebenarnya yang ingin dialihkan oleh Arkoun dengan konsepsinya ke humaniisme filosofis, yakni perimbangan spiritualitas antara humanisme literer yang literalis-tekstualis (model logosentrisme "syari'at" dalam arti sempit) dipadukan dengan spritualitas humanisme religius (minus sisi-sisi negatifnya). ${ }^{19}$ Sisi-sisi negatif dan ektrimitas dalam spiritualitas agama-agama (dalam konteks Islam) sebenarnya yang banyak dikritik oleh banyak orang sebagai wujud eskapisme atau oleh G. Santayana dicap sebagai biangnya berbagai korupsi dan penyimpangan dalam spiritualitas. ${ }^{20}$

\section{Wahdat al-Wujûd dan Wahdat al-Adyân dalam Peradaban Kontemporer}

Istilah wahdat al-wujûd dan wahdat al-adyân ${ }^{22}$ dalam sejarah sufisme selalu dikaitkan dengan pencetusnya yakni Muhyi al-Dîn Ibnu al-

${ }^{18}$ Fazlur Rahman, 1979 "Sufisme" dalam Islam New York: Anchor Books, hal. 207. Di sisni penulis tidak bermaksud mengecilkan peran berbagai "tarikat al-ma'tabarat" yang menjamur di tanah air sebagai sarana pembinaan akhlak dan pengembangan spiritualitas kaum awam. Penulis hanya mengkhawatirkan adanaya fenomena penyimpangan dalam praktek ordoordo sufisme tersebut seperti yang dikritik Rahman.

${ }^{19}$ Lihat Baedhowi, 2003, "Humanis Filosufis: Sintesa dialaektis pemikiran Arkoun" dalam Humanisme Islam. Kajian atas Pemikiran Arkoun, Tesis penulis di program Pascasarjana IAIN Sunan Kalijaga Yogyakarta, hal. 69 dst.

${ }^{20}$ Lihat, Santayana, G., 1989, "Spirituality and Its Corruptions" dalam Reason in Religion, New York: Collier Books.

${ }^{21}$ Wahdat al-wujûd berarti kesatuan wujud (Unity of existence) yakni paham yang menyatakan bahwa wujud yang hakiki hanyalah satu walaupun dalam penampakan luarnya ada banyak macam.

${ }^{22}$ Wahdat al-adyân (kesatuan agama-agama). Paham ini konon telah diperkenalkan oleh Husein al-Hallaj yang menyatakan bahwa agama-agama iu walaupun ungkapan lahiriah (syari'atnya) berbeda, namun dalam esensinya sama, yakni menuju kepada Yang Satu, Allah. 
'Arabi (w 261H/875M). ${ }^{23}$ Konsepsi wahdat al-wujûd (monisme) Ibnu Arabi tampaknya berangkat dari keyakinan yang termuat dalam sebuah hadits Qudsi: "kuntu kanzan makhfiyyan, fa ahbabtu 'an u'rafa, fa khalaqtu al-khalqa, fa bihi ya'rifûni" (Aku [Allah] dulu bagaikan harta simpanan, karena aku senang untuk dikenal, maka Aku ciptakan makhluk sehingga dengannya Aku dikenal). Ketika al-Haqq (Allah) yang Maha Suci -beserta asma-asma-Nya yang tak terhitung jumlahnya- hendak melihat esensi (Zat)-Nya Yang universal (absolut) lewat asma-asmaNya yang banyak, maka Ia ciptakan alam. Gambaran awal keagungan-Nya ini laksana penglihatan dalam cermin sebab dengan penciptaan alam semesta (yang tak berjiwa) masih seperti penglihatan dalam cermin yang buram. Maka untuk menyempurnakan penglihatan-Nya diciptakan manusia yang disamakan dengan Adam (logos adami) yang memiliki jiwa/nyawa. ${ }^{24}$ Wujud manusia sempurna inilah yang menjadi tujuan pokok pengejawantahan Tuhan (ber-tajalli) untuk menjaga dan memelihara eksistensi dunia ini. Yakni manusia selaku 'âbid sekaligus juga sebagai Khalîfatullâh $f i$ al-ardhi. Konsep manusia sempurna berpuncak pada Muhammad, yang bertitel manusia sebenarnya (Insân Kâmil).

Esensi Muhammad sebagai manifestasi Tuhan yang paling penuh, manusia sempurna ini disamakan dengan logos (kalam, firman). Hakekat Muhammad yang dimakksudkan bukan sebagai kepribadian historis, melainkan roh (esensi) yang abadi sebagai pengemban Wahyu Tuhan yang paling tinggi dan paling akhir. Muhammad sebagai Insân Kâmil adalah keseluruhan teofani nama-nama ilahi, keseluruhan alam semesta dalam kesatuannya yang dilihat oleh hakekat Ilahi. ${ }^{25}$ Dari sekilas tentang wahdat alwujûd dapat ditarik benang merah bahwa dalam puncak tasawuf atau spiritualitas Ibnu Arabi hanya mengakui satu wujud mutlak. Wujud alam adalah juga 'Ain (esensi) wujud Allah. Semua dipandang sebagai wujud dari karya-Nya dan fenomena kebesaran-Nya.

Sedangkan konsep wahdat al-adyân sebenarnya merupakan kelanjutan dari paham wahdat al-wujûd. Adanya Faham ini adalah kelanjutan dari faham yang pertama. Muhammad Husein al-Zahabi dengan mengutip Ibnu 'Arabi menyatakan: "Semua agama baik yang tergolong samawi maupun non sawami

Lihat Simuh, 1997, Tasawuf dan Perkembangannya dalam Islam, Jakarta:Raja Grafindo Persada, hal. 152.

${ }^{23}$ Lihat misalnya A.E Affifi., A Mystical Philosophy, hal. 264. Bandingan dengan L Massignon, 1913. Passion d'al-Hallaj, Paris: Libraire Paul Gauthier. Di sini Affifi berpendapat bahwa konsep wihdat al-wujûd ibnu Arabi sangat dipengaruhi oleh konsep alHulul-nya al-Hallâj.

${ }_{25}^{24} \mathrm{Ibnu}$ Arabi, tt., Fushus al-Hikam, Beirut: Dar al-Fikr, hal. 48-9.

${ }^{25}$ Annimarie Schimmel, t.tp., Dimensi Mistik dalam Islam Alih bahasa Sapardi Djok̆o Darmono, Jakarta: Gaya Media Pertama, hal. 3. 
(ardhi) tidak terdapat perbedaan. Mengingat semua pemeluk agama menyembah Tuhan yang satu, namun menampakkan dalam cara-cara dan ruparupa sesembahan mereka"26

Dari paham semacam ini sebenarnya yang harus kita maknai kembali adalah bentuk insklusivitas keberagamaannya. Karena semua agama dan apapun bentuknya mempunyai tujuan yang sama, Maka apapun bentuk ritual dari suatu agama pada hakekatnya adalah mencari suatu kebenaran mutlak. Bagi Ibnu Arabi faham kesatuan agama merupakan pandangan filsafat hidup. Orang yang mempercayai dan penuh iman dalam agamanya dengan sendirinya harus ada kesatuan agama dalam hatinya. Ini berarti sebenarnya yang dikehendaki Ibnu Arabi adalah penghindaran terhadap klaim kebenaran terhadap suatu agama dan tidak mengakui kebenaran dalam agama lain dan tidak memberi peluang kepada pemeluk agama lain untuk mengaktualisasikan ajaran yang dipeluk dan diyakininya. ${ }^{27}$

Wahdat al-adyân sebenarnya sebagai bagian dari wujud spiriitualitas Islam dalam keberagamaan dan kebersamaan. Ia merupakan perluasan sikap insklusifitas dari keyakinan pemeluk agama-agama samawi dan non samawi yang secara praktis hendak disamakan dan ditarik secara horizontal sebagai bagian insklusivitas Abrahamic Religions (Islam - Yahudi - Kristen). Wahdat al-adyân melihat sumber agama adalah Satu. Wujud agama-agama sebenarnya adalah hanya sekedar kemasan lahiriah. Ibrahim sendiri secara insklusif dinyatakan bukan sebagai seorang Yahudi atau Nasrani, melainkan seorang yang $\operatorname{Hani\hat {f}}{ }^{28}$ dan berserah diri pada Tuhan. (QS: $3 ; 67$ ).

Karena itu para pengikut Abrahamic religions sebagai hunafâ (panitents/hanifities) hendaknya sadar akan posisi ini. Sebagai seorang Muslim yang dalam dataran lahiriah mempunyai spesifikasi aqidah dan syari'ah memang harus meyakini menjalankannya, namun sebagai sufi yang mempunyai wawasan mistis dan kedalaman spiritualitas, keyakinan-keyakinan itu seharusnya tetap bisa melihat wajah-wajah agama yang sebenarnya berwajah santun, teduh dan rahmatan lil alamin. Hal ini tampaknya: juga senada dengan pernyataan teolog Katholik yang juga profesor di Universitas Tubingen, Jerman, Hans Kung ketika menyampaikan peasan moral etika perdamaian dalam orasinya di forum UNESCO, PBB: "tidak akan ada perdamaian antar bangsa tanpa adanya perdamaian antar agama-agama" (pas hal. 408 .

${ }^{26}$ Muhammad Husein az-Zahabi, 1976, Tafsír wa al-Mufassirûn, Beirut: Dâr al-Fikr,

${ }^{27}$ Keyakinan semacam itu sebenamya juga wujud toleransi atas tidak bolehnya memaksakan keyakinan sendiri terhadap orang lain sebagaimana ditegaskan al-Qur'an"tidak ada paksaan dalam agama" (QS; 2: 256).

${ }^{28}$ Hanif di sini adalah seorang yang lurus dan insklusif dalam menerima kebenaran dan keesaan Tuhan. 
de paix entre les nations sans paix entre les religions)..$^{29}$ Dengan pengertian ini bisa dipahami bahwa tanpa spiritualitas sangat mustahil perdamaian di dunia dan peradaban yang berpayung etika-global akan terwujud.

Oleh karena itu, mengingat tasawuf sebagai produk historis, maka ia perlu ditafsirkan kembali sesuai dengan konteks zamannya. Karena ia bukan sebuah warisan eksklusif dari suatu ras, bahasa maupun bangsa; Ia merupakan fenomena ruhani kemanusian biasa serta sebagai wujud tingkatan spiritualitas di mana batas-batasnya secara fisik material tidak bisa dilihat secara kasat mata. ${ }^{30}$ Karenanya konsepsi wahdat al-wujûd dan wahdat al-adyân bisa dimaknai kembali di era kontemporer tanpa harus merubah esensi spiritualitasnya. Warisan-warisan spiritualitas dari tokoh-tokoh mistik besar Islam semacam Ibnu Arabi, al-Hallaj, al-Ghazali dan sebagainya ini sebenarnya yang ingin tetap dipertahankan oleh Arkoun. Bukan sekedar pemikiran dan ritual agama yang monolitis. Kaitan pemikiran mereka dengan Kitab Suci telah menghasilkan spiritualitas yang baik dan tetap relevan dengan dunia kontemporer. Mereka telah memperlihatkan spiritualitas yang kaya tanpa ritual agama. Tetapi orang tidak mungkin mempunyai agama yang kaya dan hidup tanpa spiritualitas. ${ }^{31}$

Karenanya konsepsi wahdat al-wujûd misalnya, bisa dimaknai kembali dengan unity in plurality, unity in diversity atau unity in multiplicity. Berbagai perbedaan, pluralitas dan keberagamaan yang ada hendaknya disikapi dengan insklusivitas kebersamaan atau setuju dalam perbedaan (agree in disagreement). Pemaknaan semacam itu mengingat kita sebagai makhluk sosial dan beragama selain tidak bisa hidup di ruang hampa, juga peradaban global sekarang juga semakin membutuhkan keteduahan spiritualitas untuk mengayomi pluralitas masyarakat global yang multi agama, budaya dan bangsa.

Pada era peradaban global seperti saat ini nuansa spiritualitas dari agama agama apa pun sangat dinantikan kontribusinya. Globalitas dunia dan pluralitas agama dan budaya dalam peradaban saat ini mesti mengemban semangat kemanusiaan dan kebersamaan. Visi dan aksi spiritualitas yang ditampilkan pun tentunya mengacu pada semangat hidup kebersamaan, bersifat open ended dan juga mesti memberikan ruang keteduhan bagi orang lain (the shady spot for the others). Sedangkan yang kita rasakan selama ini visi dan aksi spiritualitas secara praksis masih terasa kering, monolit dan bersifat "close

\footnotetext{
${ }^{29}$ Hans Kung, 1989, "Le Christianisme et les religions du monde" (Kristianisme dan Agama-agama di Dunia) dalam Islamochristiana, No. 19.

${ }^{30}$ Louis Massignon, 1999, Esaai sur les origines du lexique de la mystique muselmane, ed ke-3, Paris: CERF, hal. 65-6.

${ }^{31}$ Mohammed Arkoun, 1990, "Menuju Pendekatan Baru Islam" dalam Clûm alQur'ân, 2, No. 7, hal. 85.
} 
ended". Misalnya munculnya berbagai gejala fundamentalisme ekstrim dalam realitas peradaban global. Sehingga yang terjadi dalam aras peradaban dan budaya secara horisontal adalah eksklusivitas sikap dan sistem yang cendrung saling menolak budaya dan spiritualitas orang lain (La reciprocite d'un systeme d'ecluxion) meminjam istilah Arkoun. ${ }^{31}$

Eksklusivitas sikap semacam itu yang secara politis dan ideologis tampak sekali dengan menjamurnya buku-buku best seller, sperti the Revenge of God, Awakening of Islam, dan sebagainya. Isu-isu semacam itu akhimya juga memunculkan kanter isyu yang profokatif, seperti "Clash Civilizations" yang digulirkan S. Huntington. ${ }^{32}$ Karenanya Pesan Paus Yohames II dalam ulang tahunya ke-25 sebagai kepala tertinggi di komunitas Katholik baru-baru ini untuk terus perlu menggalang dialog dengan agama-agama lain jelas merupakan sebuah insklusifitas pesan spiritualitas moral yang perlu diapresiasi dan dikembangkan dalam peradaban dan mewujudkan perdamaian saat ini:

Sedangkan dalam visi spiritualitas yang bersifat "close ended", normativitas wacana agama cendrung ditarik ke model penafsiran yang dogmatis dan mekanis sehingga cendrung menyisihkan visi, keyakinan dan keberadaan orang lain. Model semacam ini bagi kalangan tertentu memang telah menjadi Religion's way of knowing menurut D'Adamo. Yakni cara pandang keagamaan yang mengklaim bahwa keyakinannya: 1. Konsisten dan penuh klaim kebenaran, 2. Bersifat lengkap dan final (tidak menyisakan kebenaran bagi agama lain), 3. Tekstual dogmatis; menganggap teks-teks sucj sebagai jalan satu-satunya menuju kebenaran.

Pandangan semacam itu meski ingin mencari kepastian keyakinan dan spiritualitas namun mempunyai resiko sosial yang tinggi, karena dalam kenyataan sosial sikap semacam itu justru telah menimbulkan sikap kekakuan dan ketegangan tersendiri dalam hubungan dengan komunitas, agama dan budaya lain. Pandangan semacam itu dalam taraf ekstrim telah memunculkan konflik yang dipicu oleh visi dan sikap keagamaan semacam itu. Munculnya perang salib, konflik berkepanjangan di Jerusalem, maraknya teror bom di tanah air, agresi tentara AS cs ke Irak dan seterusnya bisa menjadi contoh atas kuatnya eksklusivitas visi teologis dan ideologis serta arogannya sikap politis masing-masing pemeluk agama. Semuanya itu akhirnya berujung juga dalam bentuk pencarian spiritualitas yang insklusif, modern dan toleran di mana spiritualitas semacam ini masih terus diupayakan oleh berbagai kalangan (futurolog: teolog, filosuf, sejarawan, antropolog dst).

${ }^{31}$ Lihat M. Arkoun 1984 dalam Pour une critique de la raison Islamique, Paris: Maisonneuve, hal. 53.

${ }^{32}$ Lihat Arkoun, 1995, "Clearing Up the Past to Prepare the Future" makalah dalam konferensi ICCT, UGM Yogyakarta. hal. 9. Dalam visi ideologis atau teologi dogmatis, karya Karen Amstrong, Battle for God juga dimasukkan dalam daftara karya best seller di atas. 
Keprihatinan terhadap kegersangan spritualitas bukan semata-mata monopoli Islam, tetapi merupakan persoalan dan keprihatinan bersama kaum beriman. Misalnya sedang dicari dan diupayakan oleh teolog Jerman, Hans Kung dengan kayanya Does God Exist? An Answer for Today, oleh Karen Amstrong dalam Jerusalem One City, Three Faiths, atau oleh Arkoun "Jerusalem au nom de qui au nom de quoi" (Jerusalem (spriritualitas Abrahamic Religions.pen.) atas nama siapa dan untuk maksud apa) dan "Le Concept des Societes du Livre-Livre" (Konsep Masyarakat-masyarakat Kitab) dan tokoh-tokoh lainnya. Titel-titel tersebut tampak sekali ingin memcari pijakan spiritualitas bersama, baik itu yang bersumber dari tempat bersejarah agama-agama monoteisme, seperti Jerusalem dan Mekkah. ${ }^{33}$

Karena itu, sufisme sebagai sumber dari kekayaan spiritualitas Islam justru semakin dibutuhkan bagi bangunan peradaban kontemporer. Sebab dunia tasawuf dengan metode, pendekatan dan tolok ukur kebenaranya yang intuitif, bersandar pada penghayatan batin, pengandalan atas rasa simpati dan empati, unstanding others dan bersifat universal reciprocity. Karena itu, dunia tasawuf adalah medan yang sangat posisif dalam mengembangkan spirituaitas Islam dalam bentuk berbagai social skill. Masalahnya sekarang adalah bagaimana kita memaknai kembali spiritualitas Islam dalam konteks saat ini agar tidak terjebak dalam bentuk logosentrisme teologi dan hukum Islam (syari'at dalam arti sempit) dan makna literal-tekstualis yang sering hanya berdimensi teologis, tetapi sekaligus juga bisa memberikan kekayaan makan mistis yang bisa memayungi secara spiritual bagi peradaban kontemporer.

\section{E. Penutup}

Sebagai penutup dari tulisan ini, perlu dikemukakan kesimpulankesimpulan bahwa tasawwuf adalah inti dari spiritualitas dalam Islam. Ia sudah mempunyai sejarah panjang dan telah dipraktekkan mulai dari zaman Nabi, para sahabat dan secara spesisfik dipraktekkan oleh tokoh-tokoh sufi. Tasawuf sebagai produk historis sebuah pemikiran hendaknya dikritisi dan ditafsirkan kembali sesuai dengan situasi, kondisi dan tantangan zamannya. Reinterpretasi tasawwuf sebagai wujud dari spiritualitas Islam diharapkan bisa menjadi payung bagi etika-moral dalam sebuah peradaban kontemporer.

\footnotetext{
${ }^{33}$ Mekkah sebagai pusat tempat suci sebenamya telah digunakan pusat oleh orangorang Yahudi dan Nasrani sebelum masa pra Islam. Dan tempat ini secara spiritualitas juga telah mengilhami seorang Ibnu Arabi untuk mengekplorasi simbol fisik dan ritual yang ada disana. Lihat Ibnu Arabi, t.tp, Futûhât al-Makiyyah, Beirut: Dâr al-Fikr.
} 


\section{DaFtar pustaka}

Amstrong, Karen., 1996, Jerusalem One City, Three faiths New York: Ballantine,

,---- 2000, Battle for God, New York : Ballentine,

Arkoun, Mohammed. 1982, Humanisme Arab au X/IV siecle, Paris: J. Vrin.

-.-.-., 1983, "Jerusalem au de qui au nom de quoi" dảam Islamochristiana.

-----, 1984, Pur une Critique de la raison Islamique, Paris: Maisooneuve.

----,1990, "Menuju Pendekatan Baru Islam" hasil wawancara dengan Hamid Basyaib, dalam jurnal Ulumul Qur'an, 2, No. 7.

_._-, 1992, "Le Concept des Societes du Livre-livre" dalam Interpreter.

-.--, 1995, Clearing Up The Past to Prepare the Future, Makalah pada ICCT (International Conference on Cultural Tourism), UGM Yogyakarta.

1.--, 2003, "Rethinking Islam" dalam Peta Studi Islam. Orientalisme dan Arah Baru Kajian Islam di Barat, ed. Azim Nanji, Yogyakarta: Fajar Pustaka Baru.

Baedhowi, 2003, Humanisme Islam: Kajian atas Pemikiran Mohammed Arkoun, Tesis S-2 Pascasarjana IAIN Sunan Kalijaga Yogyakarta.. .

----, 2003, "Tasawwuf Sebagai Jalan Menuju Kebenaran: Kajian Pemikiran al-Ghazali" dalam Millah, Vol. II, No. 2, Magister Studi Islam UII, Yogyakarta.

Bentounis, Khaled., 2000, Sufisme. Le Couer de l"Islam, Paris: CERF.

Elliwood, Robert, 1988, The History and Future of Faith: Religion Past, Present and to Come, New York: Crossroad,

Fox, Mathiew, 1980, Breakthrough: Meister Eckhart's Creation Spiriutality in New Transition; New York: Doubleday. 
Harun Nasution, 1973, Filsafat dan Mistisme dalam Islam, Jakarta: Bulan Bintang.

Ibnu Arabi, 1980, Fushus al-Hikam, Beirut, Dâr al-Fikr

-_--, tt., Futûhât al-Makiyyah, Beirut: Dâr al-Fikr.

Khaldun, Ibnu, tt., Muqadimah, Beirut: Dâr al-Fikr.

Kung, Hans, 1989, "Le Cristianisme et les religions du monde" dalam Islamochristiana, No. 19.

_..., 1994, Does God Exist ? An Answer for Today, New York: Crossroad

Madjid, Nurcholish, 1992, Islam Doktrin dan Peradaban, Jakarta: Paramadina.

Massignon, Louis, 1913, Les Passions d'al-Hallaj, Paris: Libraire Gauthier.

-., 1999, Essais sur les orogines du lexique de la mystique muselmane, Paris: CERF.

Nasr, SH., 1985, Living Sufism. Alih bahasa Abdul Hadi WM. Jakarta: Pustaka Firdaus,.

Rahman, Fazlur, 1979, Islam, New York: Anchor Books

Santayana, G., 1969, "Spirituality and its Corruptions" dalam Reason in religion, New York: Collier Books.

Schimmel, Animerie, t.tp, Dimensi Mistik dalam Islam, alih bahasa Supardi Djoko Darmono, Jakarta: Nusa Media.

Syukur, Amin, 2000, Zuhud di Abad Modern, Yogyakarta: Pustaka Pelajar.

Tabataba'i, tt., Mizan fi al-Tafsîr al-Qur'ân. Beirut: Dâr al-Fikr.

al-Zahabi, Muhammad Husein, 1976, Tafsîr wa al-Mufassirûn, Beirut: Dâr alFikr. 